\title{
Economic Analysis of Marketing of Chickpea in Buldhana District of Maharashtra State, India
}

\author{
S.P. Dalvi*, K.V. Deshmukh and R.D. Shelke \\ Department of Agricultural Economics, College of Agriculture, Latur, India \\ *Corresponding author
}

A B S T R A C T

K e y w o r d s
Marketing channel,
Marketing cost,
Market margin and
Price spread

Keywords

Marketing channel, Marketing cost Market margin and Price spread
Chickpea (Cicer arietinum $L$ ) is one of the major pulse crops grown in India. Chickpea has the richest, cheapest and easiest source of best quality proteins and fats. In present study, there are following routs are found in marketing of chickpea I) Producer-village-retailerwholesaler-dal processor, II) Producer-wholesaler-dal processor and III) Producer-dal processor, these three marketing channels were found in marketing of chickpea. The total marketed surplus on chickpea farm was $12.19 \mathrm{q}$, out of which $2.31 \mathrm{q}, 7.55 \mathrm{q}$ and $2.33 \mathrm{q}$ was marketed thought channel I, II, and III respectively. Marketing cost incurred by producer in the crops was comparatively low than other channels III i.e. Rs. 41.32. When it was marketed through channel II, producer incurred Rs.111.18 as marketing cost. When the produce marketed through channel- I producer paid comparatively more cost than other channels i.e. Rs.149.59.Marketing cost incurred by producer, village trader and wholesaler in channel-I, Rs. 66.00 , Rs. 31.11 and Rs. 54.48 as marketing cost and channel-II of producer Rs. 57.09 and wholesaler Rs. 54.09 and channel- III of producer Rs. 41.32 per quintal as marketing cost respectively. In case of price spread in channel-I was very high i.e. Rs. 613.98 because it was more number of middle man available between producer and consumer. In case of channel- II, price spread by processor 5306.99 per quintal of which producer received 94.21 per cent share i.e. Rs. 5000.10 in price spread Rs. 306.49. In channel- III price spread by processor was Rs. 5154.42 of which producer share was 98.95 per cent i.e. Rs. 53.96

\section{Introduction}

Chickpea (Cicer arietinum L) is one of the major pulse crops grown in India. Chickpea has the richest, cheapest and easiest source of best quality proteins and fats. It has a vast multiplicity of uses as food and industrial products. There is a need to cultivate the crop in the irrigated area as against only in the marginal land. The domestic demand and consumption, however, are much higher than production, mainly because, chickpea is a major source of protein for a large section of the vegetarian population in the country. Chickpea account for around 19.00 per cent of the gross cropped area and less than 8.00 per cent of the total food grain production of the country. Maharashtra Accounts for 17.74 Lakh hectare of area, 15.07 Lakh tonnes of Chickpea Production and $850 \mathrm{~kg} / \mathrm{ha}$ yield of 
Chickpea Crop In 2016-17. In Maharashtra, Amravati, Akola, Buldhana, Latur, Ahmeadnagar, Sangli, Dhule, Jalgaon and Solapur are major Chickpea growing Districts in Maharashtra. In Buldhana district, area under chickpea was 70,100 hectares with production of 78,400 tonnes and productivity of $1118 \mathrm{~kg} / \mathrm{ha}$.during the year 2016-17.

\section{Objective}

1. To estimate marketing cost, market margins and price spread in marketing of Chickpea.

\section{Materials and Methods}

The multistage sampling design was used for selection of district, tehsils, villages and chickpea growers. In all 90 chickpea growers were selected to collect the data on production cost, return, marketing channel, marketing cost, etc. The data were collected for the year 2016-17. At first stage the Buldhana district was purposefully selected for the present study.

In second stage, two tehsils Mehkar and Lonar from Buldhana district were selected on the basis of maximum area under the chickpea production. In third stage, three villages viz. Aaregaon, Dadulgvhan and Chincholi Bore were selected from Mehkar tehsil; similarly, Anjanikd, Dhanora and Vadgaon Tejan were selected from Lonar tehsil having the highest area under Chickpea production. In all 6 villages were considered for the study. In the fourth stage 15 chickpea growers will be randomly selected from each selected villages. Thus from 6 villages, 90 growers were selected.

\section{Results and Discussion}

The data collected from the sample farmers were analyzed as per materials and methods.

\section{Marketing of chickpea growers}

Production activity never completed until and unless the product reaches in the hands of final processor. The product can be reach to the processor by various routs which are known as marketing channel in agricultural marketing. Attempt was made in the present study to identify various marketing channels involved in marketing of chickpea. Accordingly, following marketing channel were identified.

i. Producer-village retailer-wholesaler-dal processor

\section{ii. Producer - wholesaler - dal processor}

iii. Producer - dal processor

\section{Major marketing channel in the study area}

In the studied area there are three major marketing channel are in use which are shown in table 1 Higher production sold in channelII (562 q.) followed by channel-III (173.5 q.) and channel-I (172 q.). The par cent production sold in channel-I, channel-II, and channel-III was $18.95,61.93$ and 19.11 per cent respectively. The highest production sold in channel-II followed by channel- III and channel-I respectively.

\section{Production, retention and marketed surplus of chickpea marketing}

Production, retention and marketed surplus of chickpea sold through different channels were calculated and are presented in table 2 . Production of chickpea was 14.33 quintals on 0.83 hectares and its retention for seed was 1.43 and for home consumption was 0.70 quintals. The results revealed that quantity of chickpea as $2.31,7.55$ and 2.33 quintals were marketed through channel-I, channel-II, and channel-III. Thus total marketed surplus of chickpea was 12.19 i.e. 85.06 per cent. 
Marketing cost of chickpea incurred by different intermediaries

Marketing cost of chickpea incurred by producer

Item wise per quintal cost of marketing of chickpea incurred by producer in different channels was calculated and presented in table 3.

Table.1 Major marketing channel identified in the study area

\begin{tabular}{|c|l|c|c|}
\hline Sr.No. & \multicolumn{1}{|c|}{ Channels } & Total produce sold (q) & Percentage (\%) \\
\hline $\mathbf{1}$ & $\begin{array}{l}\text { Channel-I Producer-village retailer- } \\
\text { wholesaler-dal processor }\end{array}$ & 172 & 18.95 \\
\hline $\mathbf{2}$ & $\begin{array}{l}\text { Channel-II Producer-wholesaler-dal } \\
\text { processor }\end{array}$ & 562 & 61.93 \\
\hline $\mathbf{3}$ & $\begin{array}{l}\text { Channel-III Producer- dal processor } \\
\text { Total }\end{array}$ & 173.5 & 19.11 \\
\hline & $\mathbf{9 0 7 . 5}$ & $\mathbf{1 0 0}$ \\
\hline
\end{tabular}

Table.2 Production, retention and marketed surplus of chickpeathrough different channels

\begin{tabular}{|l|l|c|}
\hline \multicolumn{1}{|c|}{$\begin{array}{c}\text { Sr. } \\
\text { No. }\end{array}$} & \multicolumn{1}{|c|}{ Particulars } & \multicolumn{1}{|c|}{ Chickpea } \\
\hline $\mathbf{1}$ & Farm size (ha) & 0.83 \\
\hline $\mathbf{2}$ & Production (q) & 14.33 \\
\hline $\mathbf{3}$ & Consumption for home & 0.70 \\
\hline $\mathbf{4}$ & Retention for Seed & 1.43 \\
\hline $\mathbf{5}$ & $\begin{array}{l}\text { Marketed surplus in channel -I (q) (Channel-I)- } \\
\text { Producer-village retailer-wholesaler-dal processor }\end{array}$ \\
\hline $\mathbf{6}$ & & 2.31 \\
\hline $\mathbf{7}$ & $\begin{array}{l}\text { Marketed surplus in channel -II (q) (Channel-II) - } \\
\text { Producer-wholesaler-dal processor. }\end{array}$ \\
\hline $\mathbf{8}$ & Marketed surplus in channel-III (q) (Channel-III)- & 7.55 \\
\hline $\mathbf{9}$ & Quantity sold in the market & 2.33 \\
\hline
\end{tabular}


Table.3 Marketing cost of chickpea incurred by different intermediaries

\begin{tabular}{|c|c|c|c|c|}
\hline Sr.No. & Particulars & Channel-I & Channel-II & Channel-III \\
\hline A & Producer & & & \\
\hline 1. & Loading/Unloading charges & - & $\begin{array}{c}10 \\
(17.51)\end{array}$ & $\begin{array}{c}10 \\
(24.20)\end{array}$ \\
\hline 2. & Transport charges & $\begin{array}{c}30 \\
(45.40)\end{array}$ & $\begin{array}{c}25 \\
(43.70)\end{array}$ & $\begin{array}{c}20 \\
(48.40)\end{array}$ \\
\hline 3. & Weighing and cleaning charges & $\begin{array}{c}2 \\
(3.03)\end{array}$ & $\begin{array}{l}10.41 \\
(18.2)\end{array}$ & $\begin{array}{c}11.32 \\
(27.39)\end{array}$ \\
\hline 4. & Market fee & - & $\begin{array}{c}4.33 \\
(7.58)\end{array}$ & - \\
\hline \multirow[t]{2}{*}{5.} & Deduction & $\begin{array}{c}34 \\
(51.51)\end{array}$ & $\begin{array}{c}7.35 \\
(12.87)\end{array}$ & - \\
\hline & Sub total & $\begin{array}{c}66 \\
(100)\end{array}$ & $\begin{array}{l}57.09 \\
(100)\end{array}$ & $\begin{array}{l}41.32 \\
(100)\end{array}$ \\
\hline B & Village retailer & & & \\
\hline 1. & Labour charges & $\begin{array}{c}9 \\
(28.93)\end{array}$ & - & - \\
\hline 2. & Transport charges & $\begin{array}{c}20 \\
(64.28)\end{array}$ & - & - \\
\hline 3. & Weighing charges & $\begin{array}{c}1.6 \\
(5.14)\end{array}$ & - & - \\
\hline \multirow[t]{2}{*}{4.} & Shop tax & $\begin{array}{c}0.51 \\
(1.64)\end{array}$ & - & - \\
\hline & Sub total & $\begin{array}{l}31.11 \\
(100)\end{array}$ & - & - \\
\hline $\mathrm{C}$ & Wholesaler & & & \\
\hline 1. & Labour charges & $\begin{array}{c}9 \\
(17.14)\end{array}$ & $\begin{array}{c}9 \\
(16.63)\end{array}$ & - \\
\hline 2. & Transportation charges & $\begin{array}{c}7.00 \\
(13.3)\end{array}$ & $\begin{array}{c}7.50 \\
(13.86)\end{array}$ & - \\
\hline 3. & License charges & $\begin{array}{c}0.14 \\
(0.26)\end{array}$ & $\begin{array}{c}0.14 \\
(0.25)\end{array}$ & - \\
\hline 4. & Electronic charges & $\begin{array}{c}0.90 \\
(1.71)\end{array}$ & $\begin{array}{c}1.30 \\
(2.40)\end{array}$ & - \\
\hline 5. & Communication charges & $\begin{array}{c}0.70 \\
(1.33)\end{array}$ & $\begin{array}{c}0.90 \\
(1.66)\end{array}$ & - \\
\hline 6. & Market fee & $\begin{array}{c}26.3 \\
(50.11)\end{array}$ & $\begin{array}{c}27.7 \\
(51.21)\end{array}$ & - \\
\hline 7. & Shop tax & $\begin{array}{c}0.44 \\
(0.83)\end{array}$ & $\begin{array}{c}0.40 \\
(0.73)\end{array}$ & \\
\hline \multirow[t]{3}{*}{8.} & Other & $\begin{array}{c}6.00 \\
(11.43)\end{array}$ & $\begin{array}{c}7.15 \\
(13.21)\end{array}$ & - \\
\hline & Sub total & $\begin{array}{l}52.48 \\
(100)\end{array}$ & $\begin{array}{l}54.09 \\
(100)\end{array}$ & $\begin{array}{l}41.32 \\
(100)\end{array}$ \\
\hline & Total & 139.01 & 111.18 & 41.32 \\
\hline
\end{tabular}


Table.4 Per quintal marketing cost, marketing margin and price spread in chickpea marketing

\begin{tabular}{|c|c|c|c|c|}
\hline $\begin{array}{l}\text { Sr. } \\
\text { No. }\end{array}$ & Particulars & Channel-I & Channel-II & Channel-III \\
\hline 1. & $\begin{array}{l}\text { Net price received by producer } \\
\text { (producer's share in consumer's } \\
\text { rupee) }\end{array}$ & $\begin{array}{l}4784.5 \\
(98.63)\end{array}$ & $\begin{array}{r}4942.97 \\
(98.85)\end{array}$ & $\begin{array}{l}5108.68 \\
(99.19)\end{array}$ \\
\hline 2. & Expenses incurred by producer & $\begin{array}{c}66 \\
(1.36)\end{array}$ & $\begin{array}{l}57.09 \\
(1.14)\end{array}$ & $\begin{array}{l}41.32 \\
(0.80)\end{array}$ \\
\hline 3. & Price paid by village retailer & $\begin{array}{l}4850.5 \\
(94.18)\end{array}$ & - & - \\
\hline 4. & $\begin{array}{l}\text { Expenses incurred by village } \\
\text { retailer }\end{array}$ & $\begin{array}{l}31.11 \\
(0.60)\end{array}$ & - & - \\
\hline 5. & Margin of village retailer & $\begin{array}{r}268.39 \\
(5.21)\end{array}$ & - & - \\
\hline 6. & Price paid by wholesaler & $\begin{array}{c}5150.00 \\
(95.39)\end{array}$ & $\begin{array}{l}5000.06 \\
(96.02)\end{array}$ & - \\
\hline 7. & Expenses incurred by wholesaler & $\begin{array}{l}52.48 \\
(0.97)\end{array}$ & $\begin{array}{l}54.09 \\
(1.03)\end{array}$ & - \\
\hline 8. & Margin of wholesaler & $\begin{array}{c}196 \\
(3.63)\end{array}$ & $\begin{array}{c}153 \\
(2.93)\end{array}$ & - \\
\hline 9. & Price paid by processer & $\begin{array}{l}5398.48 \\
(\mathbf{1 0 0})\end{array}$ & $\begin{array}{c}5207.15 \\
(\mathbf{1 0 0})\end{array}$ & $\begin{array}{c}5150.00 \\
(\mathbf{1 0 0})\end{array}$ \\
\hline 10. & Marketing cost & $\begin{array}{l}149.59 \\
(24.36)\end{array}$ & $\begin{array}{l}111.18 \\
(42.08)\end{array}$ & $\begin{array}{l}41.32 \\
(100)\end{array}$ \\
\hline 11. & Market margin & $\begin{array}{l}464.39 \\
(75.63)\end{array}$ & $\begin{array}{l}153.00 \\
(57.91)\end{array}$ & - \\
\hline 12. & Price spread & $\begin{array}{c}613.98 \\
(100)\end{array}$ & $\begin{array}{c}264.18 \\
(100)\end{array}$ & $\begin{array}{l}41.32 \\
(100)\end{array}$ \\
\hline
\end{tabular}

Note: (Figures in the parentheses indicate percentage to total) 
In channel-II share was highest on transportation charges (43.70 per cent), followed by weighing and cleaning charges (18.2 per cent) and loading/unloading charges (17.51 per cent). In channel-III share was highest on transportation charges (48.40 per cent), followed by weighing and cleaning charges (27.39 per cent) and loading/unloading charges (24.20 per cent).

\section{Marketing cost of chickpea incurred by village retailer}

Per quintal cost of marketing of chickpea incurred by village retailer were calculated and presented in table 3 . The total cost incurred by village retailer accounted for Rs.31.11 per quintal. The share of expenditure in the total cost was the highest on transportation charges 64.28 per cent followed by labour charges 28.93 per cent and weighing charges 5.14 per cent, and shop tax 1.64 per cent.

\section{Marketing cost of chickpea incurred by} wholesaler

Per quintal cost of marketing of chickpea incurred by wholesaler channel-I and channelII was calculated and presented in table 3 . The result revealed that highest of the total cost was Rs.54.09 in channel-II followed by Rs.52.48 channel-I and 41.32 in channel III. In which share of market fee was high as 51.21 per cent in channel-II followed by channel- I 50.11 per cent, labour charges 17.14 per cent in channel-I followed by channel- II 16.63 per cent. Transportation charges 13.86 per cent in channel- II followed by channel-I 13.3.

\section{Price spread in chickpea marketing}

Per quintal marketing cost, marketing margin and price spread in chickpea marketing with respect to different channels was estimated and it presented in table 4 . In channel-I price spread was Rs. 613.98 followed by channel II and channel-III Rs. 264.18 and 41.32, respectively. In channel-I, village retailer and wholesaler were the two intermediaries while in channel-II, wholesaler was only one intermediaries. But in channel-III producer are directly selling his produce to the dal processer so dal processor is ultimate consumer hence, it was observed that price spread was Rs. 613.98 in channel-I followed by that of Rs. 264.18 in channel-II and Rs. 41.32 in channel-III. Thus, net price received by producer was Rs. 5108.68 in channel-III followed by Rs. 4942.97 in channel-II and Rs. 4784.50 in channel-I. It is concluded that, the channel-III price spread is lower 41.32 as compare to channel-I, and channel-II. Thats why it best channel of marketing as compare to channel-I and channel-II.

The following broad conclusions are drawn from the present study:

Per quintal marketing cost incurred by producer in channel- I, II and III was Rs. 66.00, Rs.57.09 and Rs. 41.32 in chickpea. Marketing cost incurred by producer, village trader and wholesaler in channel-I, Rs. 66.00, Rs. 31.11 and Rs. 52.48 as marketing cost and channel-II of producer Rs. 57.09 and wholesaler Rs. 54.09 and channel- III of producer Rs. 41.32 per quintal as marketing cost respectively. In case of price spread in channel-I was very high i.e. Rs. 613.98 
because it was more number of middle man avaliable between producer and consumer. In case of channel- II, price spread by processor 5207.15 per quintal of which producer received 94.21 per cent share i.e. Rs. 5000.10 in price spread Rs. 306.49. In channel- III price spread by processor was Rs. 5154.42 of which producer share was 98.95 per cent i.e. Rs. 53.96

\section{References}

Gajbhiye, S. B. and Kakde, S. J. 2011. Marketing of chickpea in Akola district of Maharashtra. Int. J. of Com. and Bus. Mang. 4 (2): 228-230.

Govindan, K. L., 2008. Marketing of pulse in
Chhindwada district of Madhya Pradesh. Indian J. Agric. Mktg. 54 (9):128-138.

Kumari, M. and Singh, R .2016. Production And Marketing of Chickpea In Bihar: Problems and Prospects For The Farmers. Int. J. of Agril. Sci. and Res. 6 (3): 125-136.

Pichad, S.P. and Wagh, H.J. 2014. Marketing of chickpea in Amravati district. Int. J. of Com. and Bus. Mang. 7(2): 256259.

Shashikant, V.G., Dubey, L.R., and Kumar, D. (2013). Marketing of Red Gram In Gulbarga District of India. Indian J. Agric. Res.47 (5): 461-464.

\section{How to cite this article:}

Dalvi, S.P., K.V. Deshmukh and Shelke, R.D. 2018. Economic Analysis of Marketing of Chickpea in Buldhana District of Maharashtra State, India. Int.J.Curr.Microbiol.App.Sci. 7(07): 2288-2294. doi: https://doi.org/10.20546/ijcmas.2018.707.267 